\title{
Editorial \\ Modeling and Simulation of Metal Processing
}

\author{
Richard Turner (D)
}

check for

updates

Citation: Turner, R. Modeling and Simulation of Metal Processing. Metals 2022, 12, 231. https://doi.org/ $10.3390 /$ met12020231

Received: 10 January 2022

Accepted: 19 January 2022

Published: 26 January 2022

Publisher's Note: MDPI stays neutral with regard to jurisdictional claims in published maps and institutional affiliations.

Copyright: (C) 2022 by the author. Licensee MDPI, Basel, Switzerland. This article is an open access article distributed under the terms and conditions of the Creative Commons Attribution (CC BY) license (https:// creativecommons.org/licenses/by/ $4.0 /)$.
School of Metallurgy \& Materials, University of Birmingham, Edgbaston, Birmingham B15 2TT, UK; r.p.turner@bham.ac.uk

\section{Introduction}

Metal-processing operations, including casting, forging, forming, rolling, drawing, welding, machining and cutting, have provided the backbone to heavy industry and, as such, have been some of the principal drivers in the industrialization and manufacture of metal components for hundreds of years. Scientists, industrialists and metalworkers within these industries have learned more about different metallic processing routes by initially making detailed in-situ process observations and trial-and-error processing methods, which developed into instrumented experimental trials where specific properties during the processing could be measured. The technique of modeling a processing route was developed, using mathematical techniques including finite elements, finite difference and finite volume methods, to approximate and estimate the thermal, mechanical and metallurgical behavior of a component during processing.

Initial modelling methods typically allowed for the computation of predictions of temperatures, plastic deformation stresses and strains. These values could then be validated using instrumented experimental trials during and after the processing route. More modern modelling and simulation techniques used in scientific and academic communities have taken the fundamental modelling methods that were established years prior, and developed them with modern, novel scientific findings to allow for complex metallurgical phenomena, yielding a detailed metallic processing that can predict the important trends and features that a design engineer, metallurgist or specialist need to know with considerable accuracy.

This Special Issue "Modeling and Simulation of Metal Processing" was proposed as a means to combine and present some of the modern, advanced methods that the scientific community has developed to offer critical predictive insights in to the thermal, metallurgical, mechanical and service life of metallic components produced through a variety of metal processing routes. As such, a considerable number of well-written, enlightening and informative papers form this collection.

\section{Scientific Contributions}

\subsection{Bulk-Forming Processing Operations}

Jin et al. [1] reported on a constitutive modelling framework, enhanced to predict recrystallization during closed-die forging for a nickel superalloy. The applicable temperatures for the model ranged from $850{ }^{\circ} \mathrm{C}$ to $1000{ }^{\circ} \mathrm{C}$. The work was performed using the popular metal-forming FE software Deform. Truong et al. [2] presented work considering the design of an extrusion of an aluminium alloy, with a complex wall thickness measurement. They used CATIA software to perform the FE modelling work, which sub-divided the workpiece into six regions and used the Zener-Hollomon equation to predict flow stress. Modelling predictions were validated against extrusion experiments.

Rolling operations are of great importance in heavy industry. It is, therefore, not surprising that a number of papers simulating different aspects of a rolling operation were included in the collection. Yao et al. [3] developed a novel finite-difference modelling method for hot-strip rolling, applying fundamental first-principle rules of friction and loading forces. The Sellars and Tegart visco-plasticity relationship was embedded in the model, and the 
stress fields that arise in the workpiece were predicted. Li et al. [4] presented work simulating the recrystallization of cast slabs during hot-core, heavy, reduction rolling operations. A dynamic recrystallisation (DRX) model using the Johnson-Mehl-Avrami (JMA) equation was embedded in to Deform software using the associated fortran compiler. The grain sizes that arise from the heavy reduction rolling operation can then be predicted. Barrios et al. [5] presented novel work on fuzzy systems (Sugeno) algorithms, considering the workpiece's temperature upon entry into a hot-strip rolling system. The work used real data from a rolling mill. Some of the dataset was used to train the algorithms, whereas some was held back for validation activity.

Iannino et al. [6] developed a virtual simulation platform for long production-chain systems, with a particular focus on the thermal evolution during successive processes. The work fed thermal and heating stage results into a rolling framework, illustrating how a proper connection between models and communication and optimization methods lead to improved product quality.

\subsection{Welding and Molten Metal Operations}

Villa et al. [7] presented a detailed numerical modeling framework for the prediction of various metallurgical features within a Ti-6Al-4V beam weld. This included subroutines for prediction of the $\alpha$ particle size, $\beta$ grain size, martensitic needle thickness, and relative phase volume fractions, embedded within a specialist FE welding code, Sysweld. Hernandez et al. [8] simulated gas metal arc welding (GMAW), and the causal relationship between thermal cycles and the build-up of residual stress, using a general-purpose FE solver ANSYS. A double ellipsoid heat source model was used to represent the heating arc. Stresses were validated using the hole-drilling method.

Tsepelev et al. [9] studied the temperature dependence of the kinematic viscosity for iron-based multicomponent melts, particularly the role that the presence and quantity of nickel plays. The clustering of different chemical species was considered in the fundamental fluid mechanics underpinning the framework.

\subsection{Cutting Process}

Lastly, Parsian et al. [10] presented a study of novel methods to predict torsional and torsional-axial stiffness values for drill bits, some containing coolant channels, which allow for improved drill performance as the excess heat can be removed faster, but can lead to stiffness issues. The modeling method predicts the optimized locations for the coolant channels within the drill bits.

\section{Outlook}

This special issue of Metals illustrates some exciting, novel and advanced uses of different numerical and computer modeling methods to simulate widely used metal processing routes. Predictions from these models can allow designers, metallurgists and engineers to develop, improve and refine their processing methods to achieve the required outcomes.

It has been a pleasure to act as guest editor for this Special Issue. I thank the authors of these exciting papers, the reviewers who supported their selection, and the editorial team of Metals for this opportunity.

Funding: This research received no external funding.

Conflicts of Interest: The author declares no conflict of interest.

\section{References}

1. Jin, Y.; Xi, C.; Xue, P.; Zhang, C.; Wang, S.; Luo, J. Constitutive Model and Microstructure Evolution Finite Element Simulation of Multidirectional Forging for GH4169 Superalloy. Metals 2020, 10, 1695. [CrossRef]

2. Truong, T.-T.; Hsu, Q.-C.; Tong, V.-C.; Sheu, J.-J. A Design Approach of Porthole Die for Flow Balance in Extrusion of Complex Solid Aluminum Heatsink Profile with Large Variable Wall Thickness. Metals 2020, 10, 553. [CrossRef] 
3. Yao, C.; He, A.; Shao, J.; Zhao, J.; Zhou, G.; Li, H.; Qiang, Y. Finite Difference Modeling of the Interstand Evolutions of Profile and Residual Stress during Hot Strip Rolling. Metals 2020, 10, 1417. [CrossRef]

4. Li, H.; Li, T.; Gong, M.; Wang, Z.; Wang, G. Finite Element Analysis of Dynamic Recrystallization of Casting Slabs during Hot-Core Heavy Reduction Rolling Process. Metals 2020, 10, 181. [CrossRef]

5. Barrios, J.Á.; Méndez, G.M.; Cavazos, A. Hybrid-Learning Type-2 Takagi-Sugeno-Kang Fuzzy Systems for Temperature Estimation in Hot-Rolling. Metals 2020, 10, 758. [CrossRef]

6. Iannino, V.; Colla, V.; Denker, J.; Göttsche, M. A CPS-Based Simulation Platform for Long Production Factories. Metals 2019, 9, 1025. [CrossRef]

7. Villa, M.; Brooks, J.W.; Turner, R.; Boitout, F.; Ward, R.M. Metallurgical Modelling of Ti-6Al-4V for Welding Applications. Metals 2021, 11, 960. [CrossRef]

8. Hernández, M.; Ambriz, R.R.; García, C.; Jaramillo, D. The Thermomechanical Finite Element Analysis of 3003-H14 Plates Joined by the GMAW Process. Metals 2020, 10, 708. [CrossRef]

9. Tsepelev, V.S.; Starodubtsev, Y.N.; Konashkov, V.V. The Effect of Nickel on the Viscosity of Iron-Based Multicomponent Melts. Metals 2021, 11, 1724. [CrossRef]

10. Parsian, A.; Eynian, M.; Magnevall, M.; Beno, T. Minimizing the Negative Effects of Coolant Channels on the Torsional and Torsional-Axial Stiffness of Drills. Metals 2021, 11, 1473. [CrossRef] 